Portuguese Journal of Social Science

Volume 19 Number 1

(C) 2020 Intellect Ltd Article. English language. https://doi.org/10.1386/pjss_00020_1

Received I July 2019; Accepted 18 May 2020

PATRÍCIA FERRAZ DE MATOS

Universidade de Lisboa

\title{
Colonial representations of Macao and the Macanese: Circulation, knowledge, identities and challenges for the future
}

\begin{abstract}
This article intends to contribute towards the study of harbour cities, reflecting on the circulation of things and people, matters associated with national borders and multiple identities that cross paths there. Considering the history of Macao, its relationship with the Portuguese colonial empire and the challenges posed to the Macanese identity, this article intends to analyse representations of Macao and the Macanese produced in Portugal during the colonial period, considering some of them may still have repercussions today. Representations in generally accessed documents, such as the periodical press, will be analysed, as will events, such as great exhibitions, that were directed to a broader audience and which were frequently incorporated into colonial propaganda. By realizing that even today the movement towards the internationalization of Macao and China itself also involves Portugal, one concludes this is an interesting place for reflecting on power strategies, the circulation of individuals and the formation of identities.
\end{abstract}

\section{KEYWORDS}

colonial

representations

Macao

Macanese

circulation

knowledge

identities 


\section{INTRODUCTION}

This article intends to contribute towards the study of harbour cities, reflecting on the circulation of things and people, the questions associated to borders and the multiple identities related to them, based on the territory of Macao. This territory's occupation (from 1557 to 1999) began in the midsixteenth century with a gradual occupation by Portuguese sailors. Since its establishment, the city of Macao, strategically positioned on the south-east coast of China and extending towards the (western) region of the Pearl River Delta, has been connected to the development of a worldwide network and gained its position as a cross-over spot of interests, populations, religions and cultures. Macao was a significant trading post serving the trade relations between China, Japan, India and Europe for more than a century (1543-1639) until the Dutch and the British took over the trading routes when Hong Kong under British administration would eventually replace it.

The Leal Senado (Loyal Senate, the official name of Macao's town hall during Portuguese rule) was created in 1583 and extinguished in 1999, following the transfer of Macao's sovereignty to the People's Republic of China (PRC). This designation derives from a kind of emblem that was adopted in Macao during the Portuguese administration period ('City of Our Name of God Macao, There Is None More Loyal') as given by King John IV in 1654 as a reward for the city population's loyalty to Portugal during the Spanish occupation. It is also the only place in all of Portugal's territories, in the metropolis and overseas, in which the Spanish flag was never hoisted. The official title, Loyal Senate, would eventually be granted by King John VI in 1810 as a reward for the victory against Chinese pirates in the Battle of the Tigre's Mouth in 1809. Macao finally became part of the Portuguese overseas administration framework by royal decree in 1844. In 1845, Portugal declared the city a free trading harbour.

Macao was also the centre for the activities of the Catholic missions in China and Japan, with the first Jesuit church and school built there in the early seventeenth century. The remaining façade of St Paul's Church testifies to the importance of Macao in the history of the dissemination of Catholicism and the knowledge of Chinese and Japanese cultures and languages in the West. This grand stone façade, designed by an Italian Jesuit with the support of Japanese Catholic refugees residing in Macao, with biblical quotes in Chinese and statues depicting missionary saints, is today represented as the city's symbol and is the Macao Special Administrative Region's (MSAR) main tourist attraction, being classified as the World Heritage Site.

By living in relative isolation from the Portuguese metropolis between the sixteenth and nineteenth centuries, the Macanese developed a local creole culture by incorporating several influences they received from Eastern Asia's maritime world. By doing so, they were able to retain their lifestyle, traditions, language, gastronomy and professions traditionally associated with the local government. Macao is, in fact, a complex space, not only from a historical point of view but also in its current framework. It is a border city, dependent on the balance between different political forces and has suffered several transformations in the last few decades. Further, it is marked by its ethnical complexity. While the inhabitants of Macao included many people from South Asia (Malayans, Japanese, Indians, Timorese and even Africans), a Portuguesespeaking Catholic society was formed after the Portuguese arrived. Over time, this led to the emergence of the Macanese, a population that was 


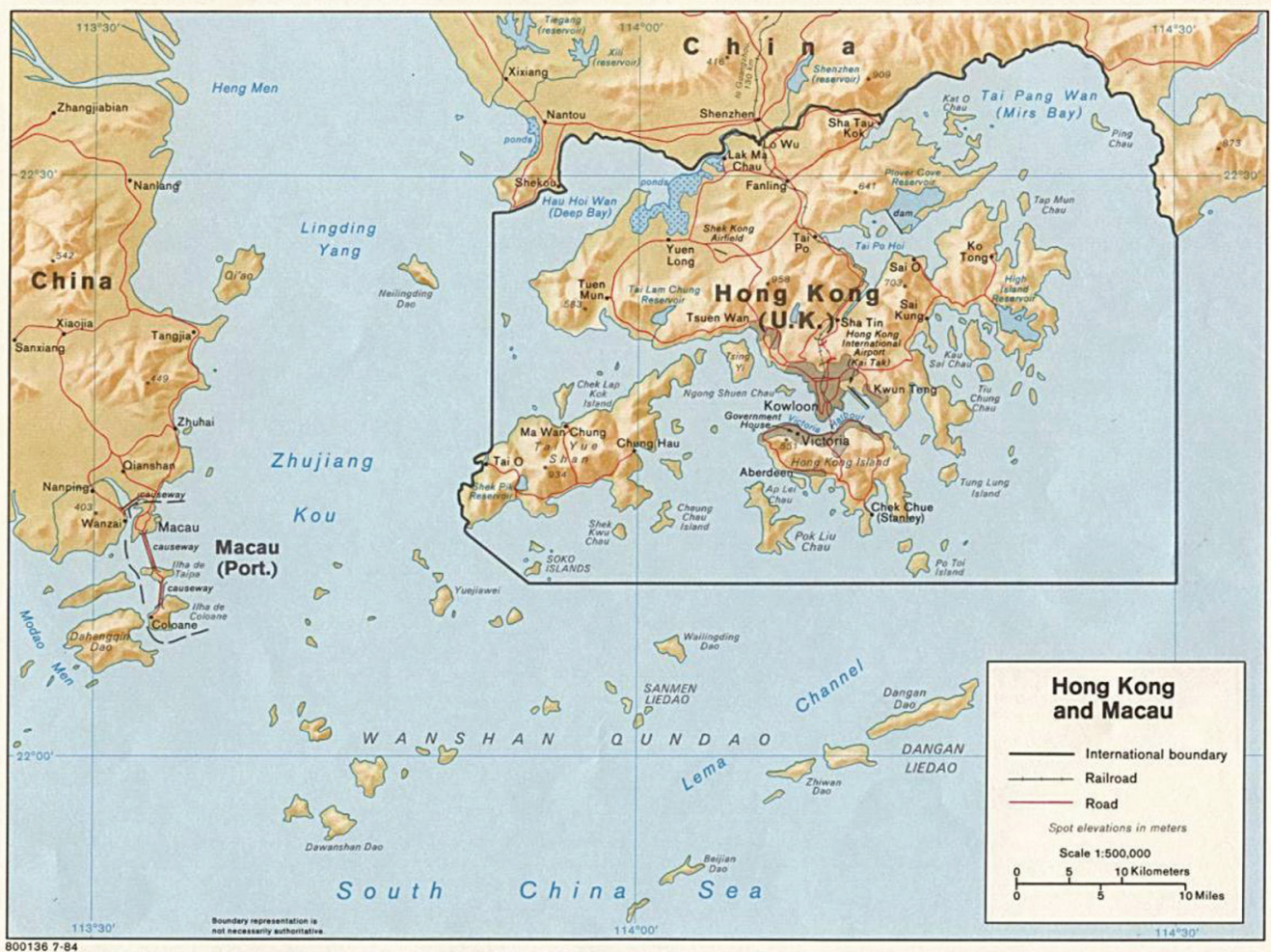

Figure 1: Map of Hong Kong and Macao (1984).

fundamentally Portuguese, but which retained local characteristics (de PinaCabral and Lourenço 1993).

A 'creole culture' was therefore born, with its own dialect (patuá) and also its own institutions and gastronomy. However, throughout time, this space also included a Chinese population (not necessarily distinguishable from the remaining population) and a local creole population that can be differentiated based on two features ${ }^{1}$ : the fact they are subjects of the king of Portugal, and also Catholic. According to João de Pina-Cabral and Nelson Lourenço (1993), the main ethnic categories in Macao are the Portuguese, the Macanese and the Chinese. The main self-identification vectors used by people for selfcategorization or to categorize others as Macanese are language (associating the individual or their family with the Portuguese language), religion (individual or familiar identification with Catholicism) and miscegenation (European and Asian blood). However, not all vectors must necessarily be present (de Pina-Cabral and Lourenço 1993). However, according to most recent demographic statistics of Macao, there are other major ethnic groups (i.e. migrant workers from the Philippines, Vietnam, Myanmar and Indonesia) that are very much more representative than the Portuguese (estimated at around 2000 nationals in 2016) (Administrative Public Service Bureau of the Macau Special Administrative Region 2020).
1. For a wider perspective of the study of kinship in China, in the northern and southern regions and the rural and urban areas, from the end of the Imperial period to the creation of the PRC, see Brandtstädter and Santos (2009). 
Since the late nineteenth century, the Portuguese administration settled gradually and the Macanese, intending to maintain the privileges that distinguished them from the Chinese community, were forced to minimize their creole culture and to incorporate elements of Portuguese culture. Therefore, their creole tongue became mainly a household language that disappeared in less than a century. Its gastronomy, one of the most ancient examples of fusion cooking in the world, survived only in some families and is prepared only on rare occasions (Gaspar 2014: 23).

The Chinese movements against the foreign presence in Macao and Hong Kong intensified after the Second World War, mainly with the proclamation of the PRC in 1949. Its ambivalence has therefore marked the Macanese identity: the Macanese are a community that results from a long inclusion and exclusion process that evolved based on external conditions; its borders also remained undefined and diffuse between different social universes (Gaspar 2014: 22). Although the great majority of the population is ethnic Chinese, the Macanese are deeply associated with the identity and the history of Macao. These bonds are explicitly combined in the Portuguese term filhos da terra (children of the land) (Amaro 1988).

The Macanese creole community always allowed a high degree of ambiguity, where assignment to an ethnic group is not imposed on the Euro-Asians due to their appearance, but results instead from personal identity options. The Portuguese rules for racial issues were always considerably different from those typical of the British empire at its peak. For this reason, it is important even today to draw a clear line between ethnic relations in Hong Kong and Macao (Gaspar 2014: 23). An ancient Macanese once said: '[a] Portuguese mestiço was called Portuguese. An English mestiço was called half-caste' (de Pina-Cabral 2002: 22). This explains why in Hong Kong, as late as the 1970s, it was common practice to distinguish between Europeans, Euro-Asians and Portuguese. The latter category included mainly the descendants of the Macanese families and was a result of centuries of interethnic marriages (Boxer 1963, 1969).

Based on Macao's history, its relationship with the Portuguese colonial empire and the challenges facing the Macanese identity even today, I intend to identify representations of Macao and the Macanese produced in Portugal during the colonial period, some of which may even have repercussions today. For this purpose, I shall examine these representations in globally accessible documents, such as the periodical press, and in events directed to a general audience, such as great exhibitions, which were often integrated into the colonial propaganda context during the first half of the twentieth century. In this process, I was inspired by Stuart Hall (1997), according to whom we can define representation as the process through which: (a) first, we can correlate all sorts of objects, persons or events, real or imaginary, with our conceptual system, which organizes, classifies and relates all our concepts or mental representations in a significant way and that, as a general rule, is shared by the other members of our culture; (b) second, we can convey meanings and concepts to others using a common language, comprised by signs that represent concepts and conceptual relationships. In this sense, to represent is the process through which objects, concepts and signs interrelate and produce meaning. 


\section{MACAO IN COLONIAL PERIOD REPRESENTATIONS}

According to the 1933 Organic Charter that divided the empire into 'eight colonies', Macao was one, alongside Cape Verde, Guinea, São Tomé and Príncipe, Angola, Mozambique, the State of India (Goa, Daman and Diu) and Timor, of these colonies (Figure 2). ${ }^{2}$ The 1930 Colonial Act established the jurisdiction regarding the populations of São Tomé and Príncipe, Guinea, Angola, Mozambique and Timor, but the people of Cape Verde, the State of India and Macao possessed a special status. In 1945, after the amendment of the Organic Charter, it was stated that 'in the State of India and the colonies of Macao and Cape Verde their populations are not classified as indigenas nor submitted to the indigenousness regime'. They are, therefore, allowed the status of 'citizen' (de Matos 2013a: 51).

From the analysis of the Organic Charter defining the Portuguese colonial empire and characterizing its populations, as well as being based on the representations produced in the spaces it comprised (on scientific, political and propaganda levels), we can conclude that, generally, there was a hierarchy among the inhabitants of those territories: Angolans, Guineans and Mozambicans occupied the lowest social layer, followed by the Timorese and São Tomeans, with the inhabitants of the State of India, Macao and Cape Verde occupying a higher position (de Matos 2013a).
2. The Carta Orgânica (Organic Charter) published in the Diário do Governo was enacted by Decreto-Lei no. 23 228 of 15 November 1933, later amended by Law no. 1948 of 13 February 1937, passed by the minister for the colonies Francisco Vieira Machado (1898-1972).

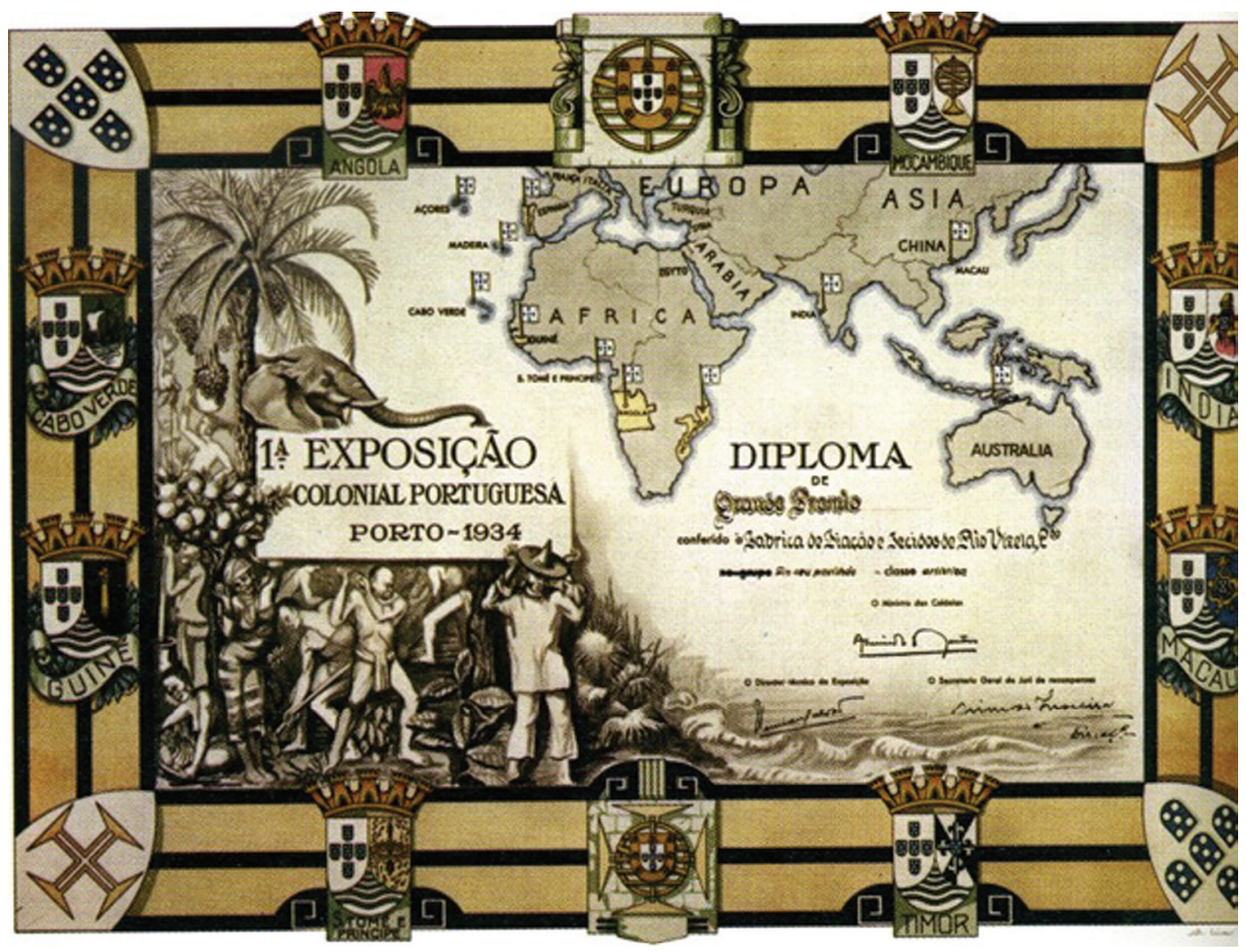

Figure 2: Map with the territories administrated by the Portuguese, including Macao (Álbum-Catálogo Oficial 1934). 
In the context of the Exposição Colonial Portuguesa (Portuguese Colonial Exhibition), which took place in Porto in 1934, people from the colonies, including Macanese, were brought to the then metropolis. Some were depicted in a set of postcards at this exhibition and the 1937 Exposition Universelle in Paris (Figure 3). In the official catalogue of the exhibition, Macao is referred to as the 'pearl of the Orient' and one of the most densely populated places in the world: according to the latest census at that time, the population was divided into 'yellows', 'whites' and 'blacks and mestiços', the latter being grouped in one same category. There was also the Portuguese from the metropolis, the 'white' and 'assimilated' Portuguese born in the colony, the 'Chinese-origin individuals, naturalized as Portuguese' and 'foreigners' (Álbum-Catálogo Oficial 1934: $385-86,371)$, that is, despite the categories used, the catalogue's text confirms the existence of a substantial population diversity in Macao. This exhibition included the Macao Street, in which a pavilion with the same name was installed to serve as a tearoom (Figure 4). An orchestra of Chinese musicians would also play in that pavilion (Figure 5).

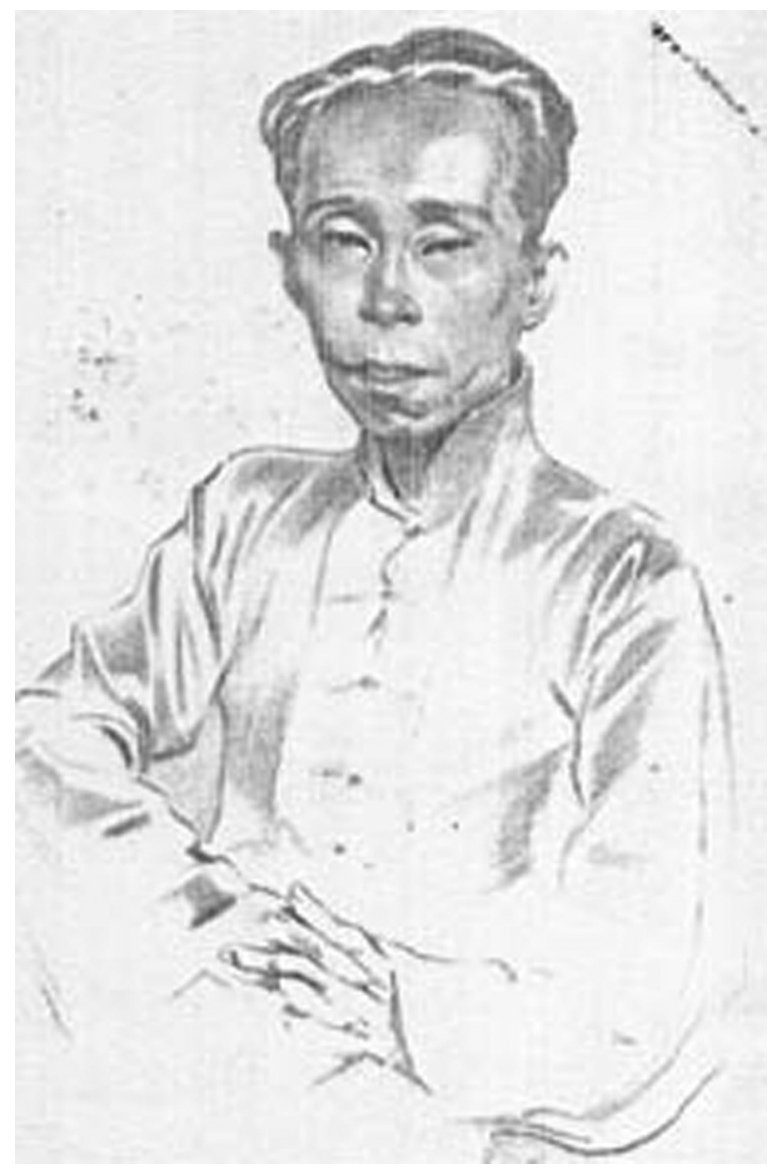

Figure 3: Postcard from the 1934 Portuguese Colonial Exhibition. Império Português. Lu-fu, Macau, «músico china de Macau» ('Portuguese empire. Lu-fu, Macao, Chinese musician from Macao'). 


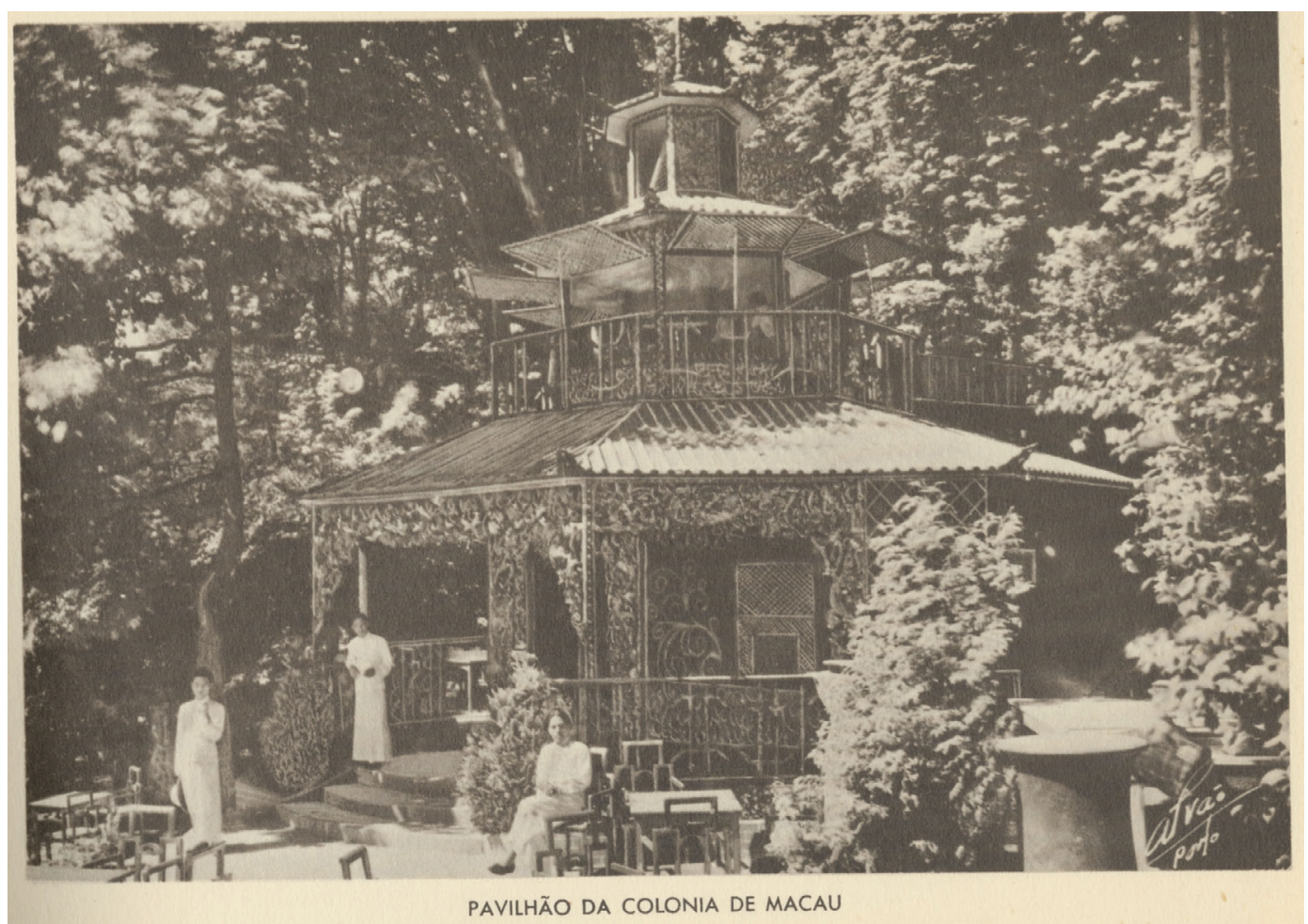

Figure 4: Macao pavilion (Álbum-Catálogo Oficial 1934).

The Porto Colonial Parade of 30 September 1934 (at the end of the Portuguese Colonial Exhibition) included the Macao float, which was flanked by 'natives from the colony' and a Chinese pagoda with four dragons: elements considered representative of the territory and its differences (O Cortejo Colonial no Porto 1934). As a rule, social sophistication and elegance are recognized in the natives of Macao and India, as opposed to the natives of the other overseas territories. On the other hand, from the descriptions found, we may infer that the visitors to the exhibition appreciated the music played by the Chinese orchestra more than the African drumming (batuques) that was also part of the event. All these phenomena combined led to the belief that there was greater proximity between Asians and Europeans than between Africans and Europeans.

Macao was included in the colonial section of the 1940 Lisbon Exhibition of the Portuguese World, in what was then known as the Colonial Garden. To represent Macao, a street was built (Figure 6) - a work by Saúl de Almeida and Raúl Campos - with elements considered to be typical, such as restaurants, and it incorporated individuals performing wood crafts, for example, in an attempt to reproduce the Macanese way of life. The street had the Macao pavilion, shops, a lottery house, fan-tan (traditional game), a temple (pagoda) and a house for its 'natives'. Overall, the colours used were gaudy and mainly scarlet (Figure 7). These representations partially remind us of what Edward Said (1978) called orientalism, that is, the translation of how the West idealized the East in several domains, from literature to science and art (Figure 8). 


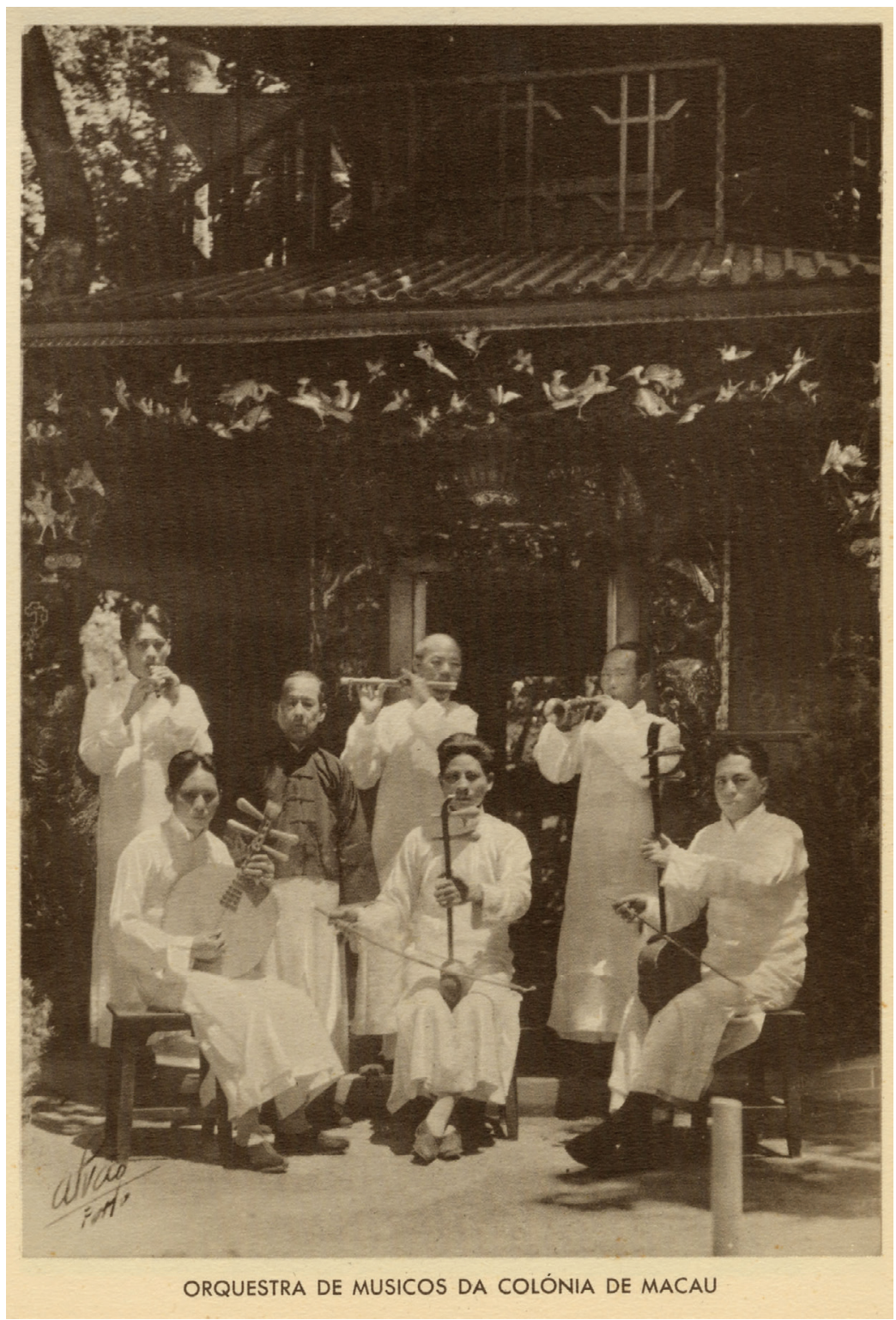

Figure 5: Orchestra of Chinese musicians (Álbum-Catálogo Oficial 1934).

In the report by Leopoldo Danilo Barreiros (who accompanied the Macanese during the trip) on the 'indigenous representation' of Macao (although the indigenous status was never used in this territory), we note that 'one female singer and attendant, two coolie carters who doubled as bankers in fan-tan and three camphorwood carvers' were chosen to take part in the exhibition (Barreiros 1940). According to Barreiros, who named himself 'manager and director', betraying the paternalism towards populations then under the Portuguese administration, only three of the artisans and 'coolies' 


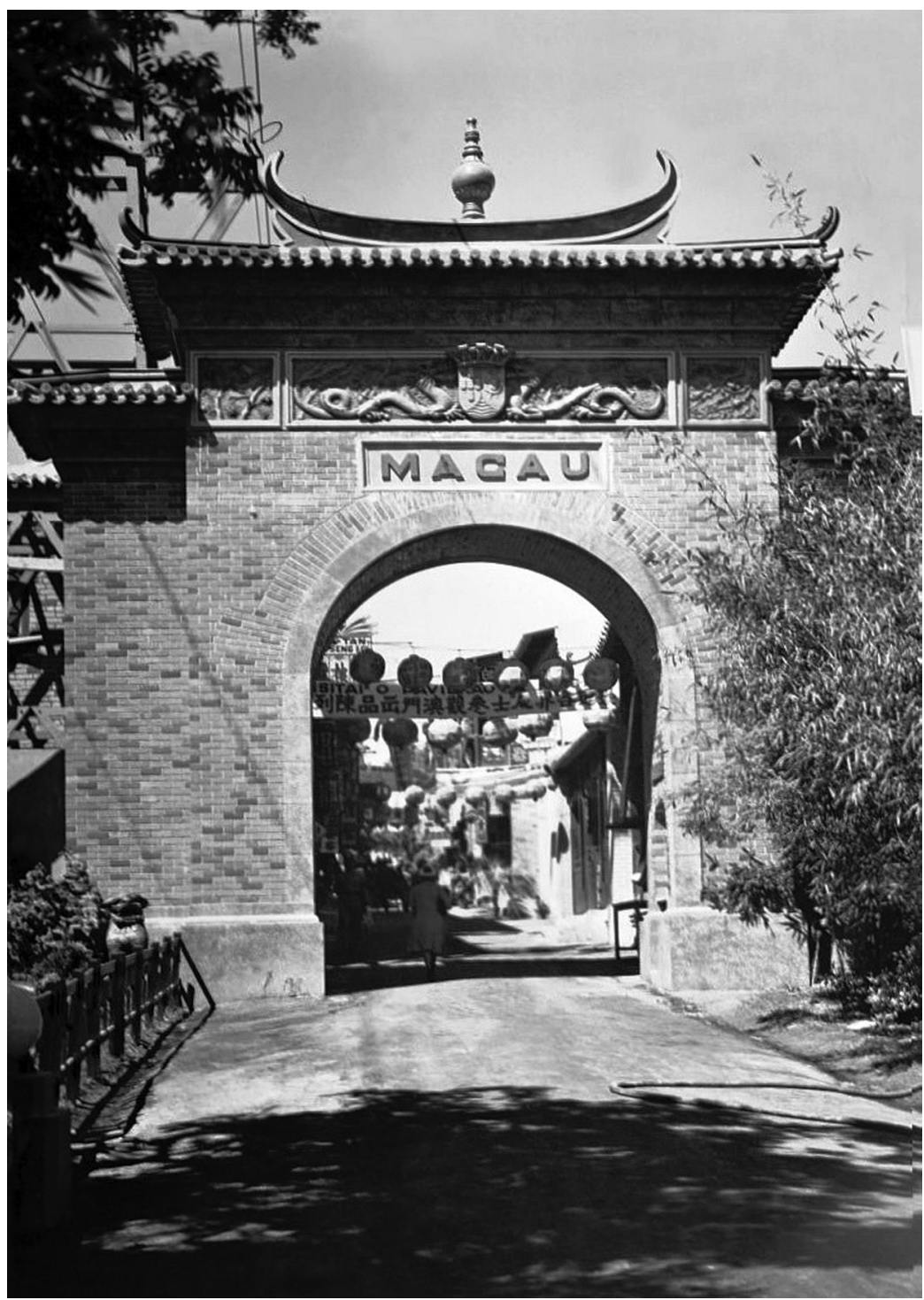

Figure 6: Exhibition of the Portuguese World, Lisbon, 1940, Macao Street (Restos de Colecção 2012).

spoke Portuguese (Barreiros 1940). Despite being a 'Portuguese representation', not all members had mastered the language of Camões. Besides, the journey was not a peaceful one:

On their arrival in Hong Kong, the representation was installed in horrific conditions on board the ship that was to take them to the Dutch Indies. The tickets bought for them in Lisbon were deck tickets, which did not entitle them to a bunk [...] As the passengers were not indigenas of primitive and rudimentary civilization but rather people accustomed to everyday conveniences [...] it was necessary to find a solution 


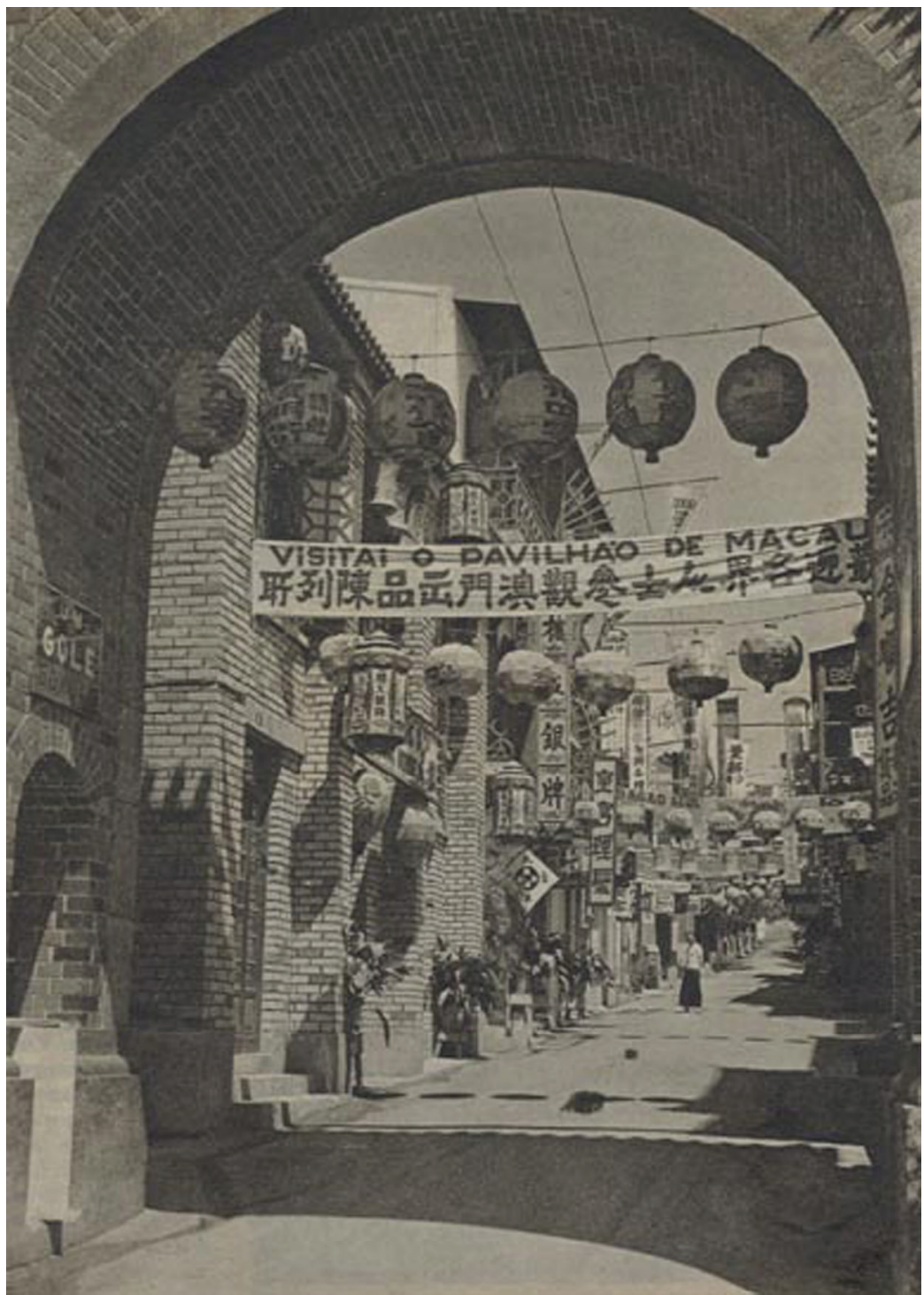

Figure 7: A rua de Macau, pedaço da China dos portugueses ('Macao Street, Portuguese piece of China') (Anon. 1940, O Século).

to the matter. The singer and her attendant were given berths in second class [...], and the men were berthed in a sectioned-off part of the hold equipped with newly-purchased camp beds.

(Barreiros 1940)

One is therefore able to see that there were significant differences in the universe of the individuals belonging to the territories administered by Portugal, according to their origin or social level. In other words, if these people had originated from African territories, there would probably have been no effort made to improve their accommodation during the journey. 


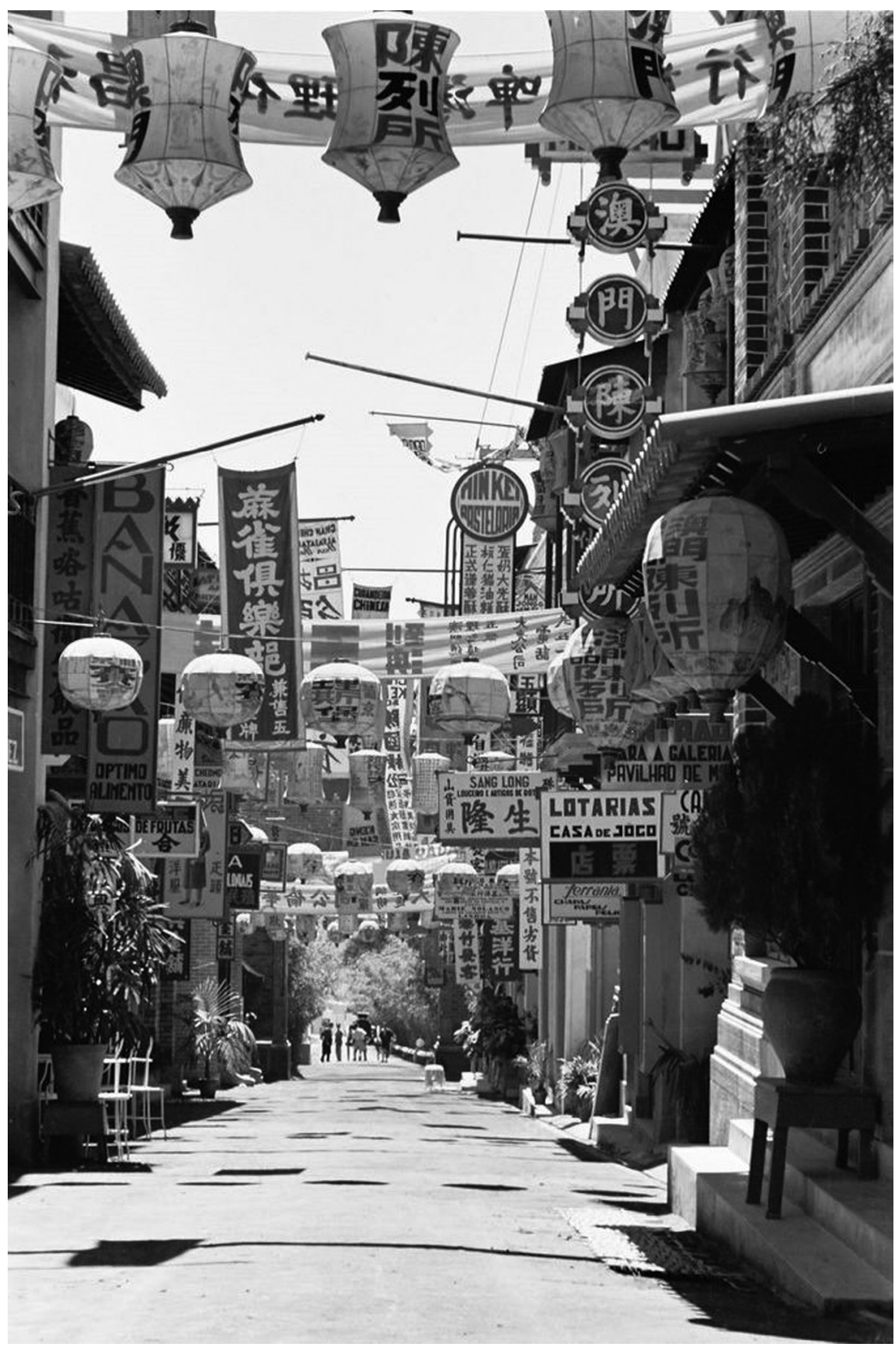

Figure 8: Exhibition of the Portuguese World, Lisbon, 1940, Macao Street (Restos de Colecção 2012).

When the Macanese representation arrived at the Dutch Indies, it was transferred to the cargo ship, and here they were accommodated 'in a huge cabin with ten beds, the ship's hospital'. When they arrived in Portugal, the Macanese were welcomed by João Mimoso Moreira (assistant to the director of the colonial section, Henrique Galvão [1895-1970]) who settled them at the Colonial Garden. They enjoyed some outings from the exhibition site 


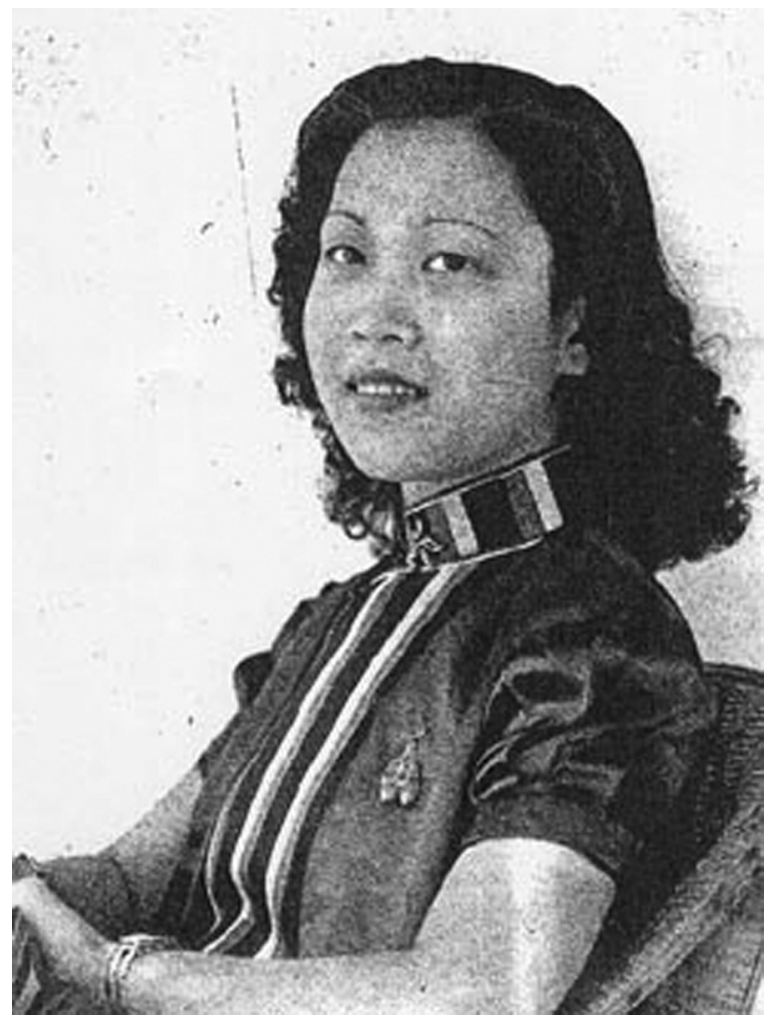

Figure 9: Illustrated postcard. Secção Colonial da Exposição do Mundo Português 1140 - Duplo Centenário - 1940. Cliché Salgado. Beleza macaísta ('Colonial section of the Exhibition of the Portuguese World 1140 - Double centenary - 1940. Salgado cliche. Beauty of Macao').

but, according to their delegate, were always'escorted by the most trustworthy people' (Barreiros 1940).

During this exhibition, several photos of Macanese were passed around on postcards that, on the one hand, exalted the beauty of the women (Figure 9) while, on the other, using the language of 'types' that sought to identify human variabilities at a phenotypical level (Figure 10). Not only in the postcard captions but also in the exhibition's catalogue we realize that it is mainly the texts that offer stereotypes of Macao's inhabitants. For example, the catalogue, organized by Henrique Galvão, who was in charge of the colonial section, states that in Macao the 'homogeneity of slanting eyes' prevailed, although there was a 'multiplicity' of 'Chinese types' from 'the high stature and clear skin of the northern Chinese to the shorter and darker southern type'. Despite the Chinese influence, the Macanese resulted from the 'crossing of races where the Portuguese traits prevailed'. The 'Chinas', he mentions, had a great tendency to acquire superfluous habits, but their three primary'addictions' were 'tobacco, opium and gambling', the most popular being the fan-tan. In 1940, according to Galvão, only a few people understood the 'dense patuá that was once spoken', while the Portuguese spoken was as correct as in the metropolis. This colony had an intense social life, and the activities developed 


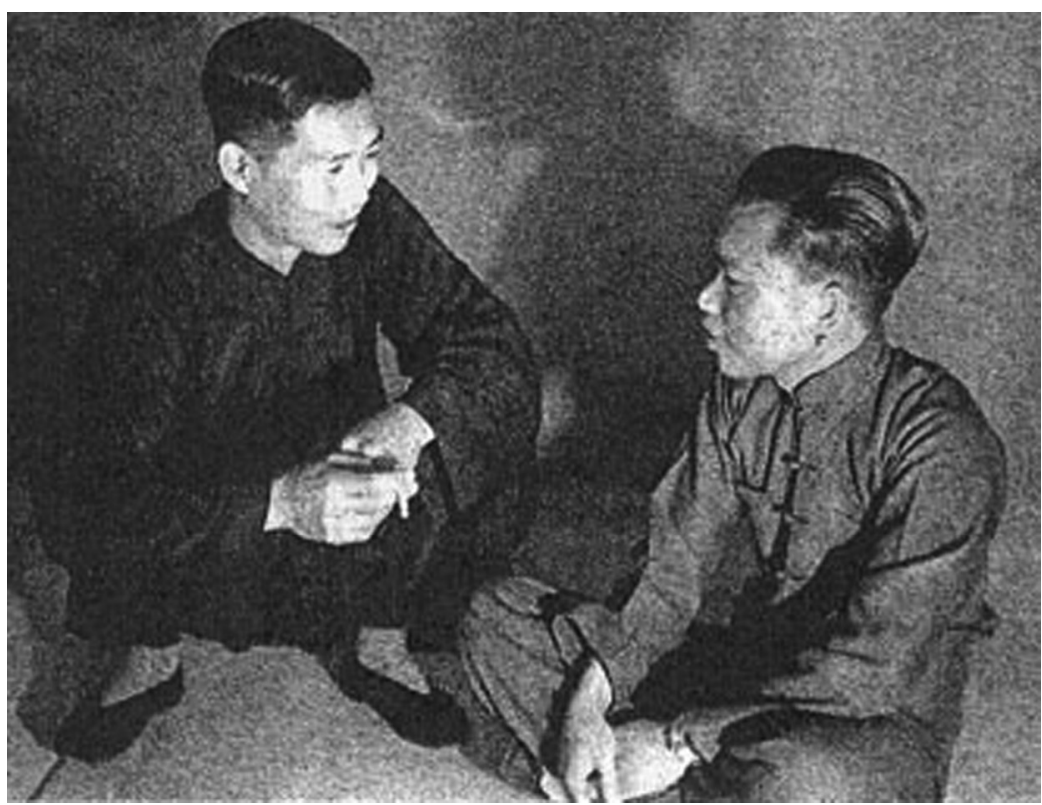

Figure 10: Illustrated postcard. Secção Colonial da Exposição do Mundo Português 1140 - Duplo Centenário - 1940. Cliché Salgado. Tipos de Macau ('Colonial section of the Exhibition of the Portuguese World 1140 - Double centenary - 1940. Salgado cliche. People of Macao').

revealed 'civilized and educated people'. Besides, the prevailing religion was Catholicism as a consequence of ancient and careful missionary activity. Therefore, although the author does not mention it explicitly, despite their superfluous habits and their addictions, the Macanese were a'people' considered 'civilized and educated'. This component was materialized in the correct use of the Portuguese language and in the fact that the religion was mainly Catholicism (Galvão 1940: 142-55).

Macao was also represented in Leitão de Barros's Lisbon Historical Parade in the Praça do Império in 1947, which included the elements considered the most representative and important in Portuguese history. I realized this by viewing two documentaries: O Cortejo Histórico de Lisboa (Ribeiro 1947) by António Lopes Ribeiro, and O Cortejo Histórico com a Representação de Todas as Colónias Portuguesas em Carros Alegóricos (Vieira 1947) by Manuel Luís Vieira. The parade included representations of characters associated with the nobility, soldiers or horsemen from the sixteenth, seventeenth and eighteenth centuries. Macao's float had two dragons and a large golden Buddha, evoking the elements that were used frequently to represent this Asian space. In general, the individuals represented here were seen as evidence of the Portuguese colonization's success, considering the 'empire' and its populations as part of the nation.

Still, in the 1940s, Macao was also depicted in a pavilion at the Portugal dos Pequenitos ('Little people's Portugal'), an exhibition park for children and the young, designed by Dr Fernando Bissaya-Barreto (1886-1974) and the architect Cassiano Branco (1897-1970), which was inaugurated in Coimbra in 1940. Its structure was divided into five main components: 'Portugal Overseas', 'Monumental Portugal', 'Coimbra', 'Metropolitan Portugal' and 'The Children's 


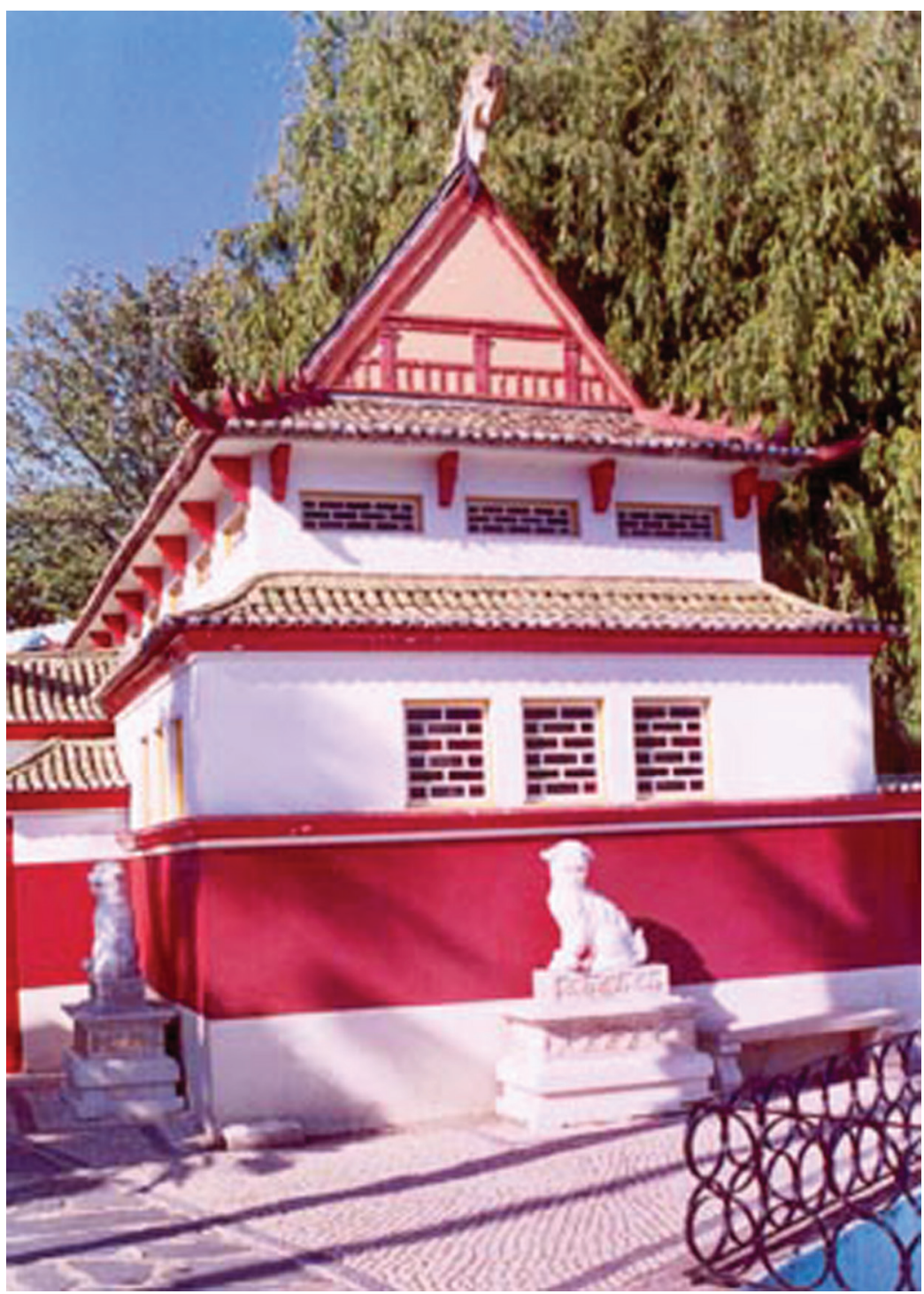

Figure 11: Pavilion of Macao. Photography: Patrícia Ferraz de Matos, 2002.

House'. The 'Overseas' represents the countries once administered by the Portuguese in Africa (currently the Portuguese-speaking African countries) and Macao, India, Timor and Brazil, and also the nation's islands - Azores and Madeira. This space, therefore, gathers a representation of Portugal that intends to enlighten us about its inhabitants: what they do, their culture, their activities and their artefacts. On the stone pillar at the entrance of the Macao pavilion, one can read: the 'Portuguese presence remained until the twentieth century, and 31 December 1999 marks the end of the territory's Portuguese administration'. Around this pavilion, there are several lions and, on the roof, two representations of dragon heads, that is, figures taken from the oriental imaginary (Figure 11). 


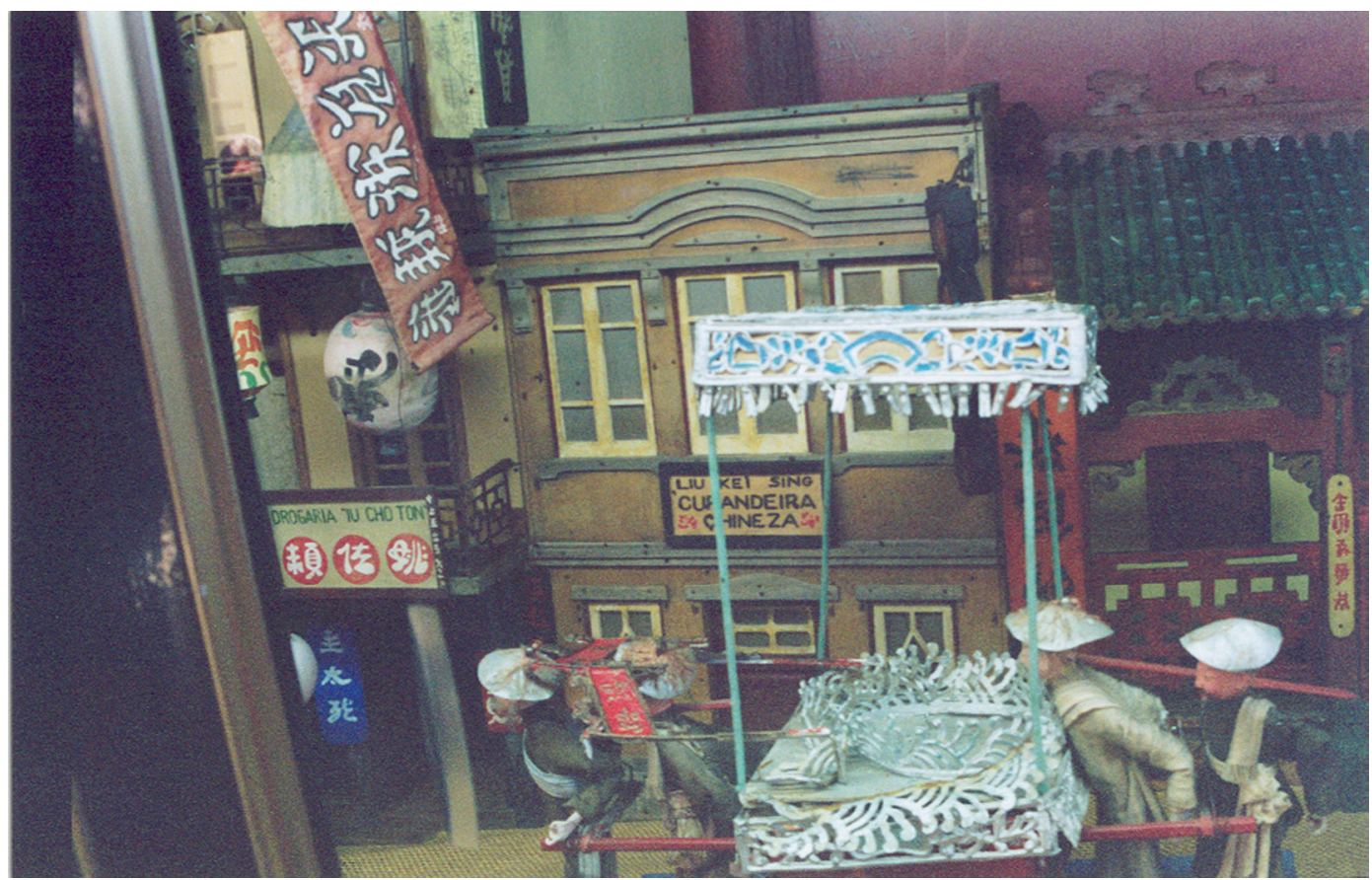

Figure 12: Interior of the Macao pavilion. Photography: Patrícia Ferraz de Matos, 2002.

In the Asian pavilions (of India and Macao) at Portugal dos Pequenitos, we find elements that, as opposed to what we see in the African pavilions in the exhibition space, suggest another stage of 'civilization', on the one hand, and of acculturation, on the other. In the case of the Macao pavilion, we refer to the photograph of the Infante D. Henrique National School - the symbol of alleged civilization and Portuguese presence in the territory - and the scale models depicting the streets, with the captions'dentist','guesthouse', 'chemist', 'Chinese healer', 'tailor', 'dresses', 'building contractor' (Figure 12). Therefore, these elements seem to show us a more developed society than those of Africa or East Timor (de Matos 2010). These aspects reinforce the similarity between this exhibition space, which can still be visited today, and the previously examined exhibitions in respect of the depiction of human groups and the establishment of civilizational hierarchies (de Matos 2014).

Also, the texts made available to primary and secondary school readers during the Estado Novo (New State) helps us understand the way Macao and the Macanese were represented. The analysis of those books confirmed that, among the set of Portuguese colonies as a whole, Macao was built and depicted to respect the differences between the two civilizations without merging them. There is a text by Ferreira de Castro, dating from 1953, with the title 'Macau', on the aspects of its natural and urban landscape (Tavares 1953: 267-71). It is interesting to see how the urban landscape was used to reflect on the way the region was organized. According to this text, the Almeida Ribeiro Avenue - the 'main artery of the territory', which crosses from one side of the peninsula to the other, from the end of the Portuguese city to the end of the Chinese city - 'shows two different ancient civilizations that never merged, 
despite the long-lasting contact' (1953: 268-69). From the Loyal Senate Square onwards 'it loses its European traits and becomes a Chinese street' (1953: 269). On the streets of Macao, we will find 'vertical boards with advertisements in Chinese and also blinds, lanterns, dragons and strange characters in lacquered metal, in a picturesque and immense whirlwind of shapes and colours' (1953: 270). We also see many 'Chinese stores, Chinese fabrics, pharmacies, knickknacks, sequins, herbalists, restaurants, gambling houses, always with the same accumulation of exotic lines' (1953: 270).

These descriptions point to a different strategy from the one applied in Africa, where settlers sought to impose a different order: villages were torn down and others built alongside them, but with a different alignment; children were picked up from their homes to attend Sunday school and mass. There the aim was to obtain workers for farms, as well as for building bridges and roads. Therefore, while the above text focuses on an urban landscape, we can see how the city was organized in terms of population. Here, the order of the elements was not changed: the habits and aesthetic taste of the Chinese were respected. The sole small alteration regarded the promotion of better hygiene.

The post-Second World War period, mainly from the early 1950s onwards, was marked by the nationalist and ideological strengthening of the Estado Novo. This strategy sought to thwart the ideas conveyed through the pressure of international anti-colonialism and by the nationalist movements, both Asian and African. In 1951, the Portuguese law about the colonies was changed: they were now called overseas provinces, and several of the country's institutions incorporated the new designation, seeking to depict a pluricontinental and multiracial country.

Based on the materials analysed, produced in the context of colonial propaganda or aimed at the majority of the Portuguese population, we can conclude that Angola and Mozambique, the two settlement colonies, are given greater prominence compared to Macao or Timor, for example (de Matos 2013b). Distance, on the one hand, and communication difficulties, on the other, will have also contributed. The distance is observed both at the geographical and cultural levels (language, gastronomy, religion, values, etc.). Cultural differences include the fondness for gambling, often considered an addiction or criticized due to the excessive desire to make money regardless of the means. On the other hand, despite the exotic and different character often attributed to Macao, it bears several recognizable elements of Portuguese culture. Besides being occasionally referred to as a territory that has always defended Portuguese sovereignty, it is also held up as an example of Portugal's imperial calling in respect of civilization and the evangelization of territories across the world.

\section{PRESENT-DAY MACAO}

The Sino-Portuguese Joint Declaration for the future of Macao, signed in 1987, began the negotiations between the Portuguese and Chinese authorities and was marked by a close cooperation and smooth transition of the final overseas territory under Portuguese administration. Based on that document, and like events in Hong Kong, the MSAR was created with a certain degree of political autonomy, a local government and its own legal framework (the Basic Law), allowing for the continuation of the legal, social and cultural systems 
operating during Portuguese administration until 2049, including retaining Portuguese as a second official language.

Macao was annexed to the Chinese administration under the 'one country, two systems' policy on 20 December 1999. ${ }^{3}$ It became the second Special Administrative Region of the PRC after Hong Kong in 1997. Its designation since then is MSAR of the PRC. This was the outcome of a preparation and negotiation process developed over several years, which considered continuity and stability, as well as the maintenance of the good relationship between Portugal and China.

Despite Macao's considerable reach, with its historic centre classified as a World Heritage Site by UNESCO in 2005 in consideration of its SinoPortuguese legacy, the territory's exponential growth was due to the liberalization of the gambling industry in 2002 and its subsequent conversion into a world gambling capital. Macao currently has about 690,000 inhabitants, which makes it the most densely populated city in the world, and is now a tourist destination attracting more than 30 million visitors every year (Administrative Public Service Bureau of the Macau Special Administrative Region 2020).

Nowadays Lusophony is primarily promoted in Macao through such initiatives as the Lusofonia Festival by the MSAR and Portuguese-Speaking Countries'Theatre Festival (TEATRAU). This movement happening in Macao (Morais 2018) sometimes seems to be inspired by the luso-tropical theory, which historically associates the Portuguese with a particular aptitude in adapting to other territories and populations and to developing a specific colonization process (Cahen and de Matos 2018).

In 2003, the Forum for Economic and Trade Cooperation between China and Portuguese-Speaking Countries, also known as Forum Macao, was created. It was an initiative of the Chinese central government in coordination with seven Portuguese-speaking countries (Angola, Brazil, Cape Verde, Guinea-Bissau, Mozambique, Portugal and East Timor), and with the collaboration of the MSAR government. São Tomé and Príncipe joined the group in 2017. The Forum celebrated its fifteenth anniversary in 2018 (Figure 13), and its Permanent Secretariat's webpage states that it is aimed at 'promoting economic and trade exchanges between China and Portuguese-speaking Countries, by using Macao as a connecting platform between those places' (Forum Macao 2018b). On this same site, on the link to cultural exchanges between China and Portuguese-speaking countries, it says Macao 'links the richness of Chinese culture with the unique characteristics of Lusophone culture $[\ldots$ and $]$ is committed to promoting cultural exchange and cooperation [...] as well as to diversifying its domestic industries' (Forum Macao 2018c). It also states that ' $[\mathrm{t}]$ he "Cultural Week of China and Portuguese-speaking Countries", the "Lusofonia Festival" and the "Macao, Latin City Parade" are three events that serve to enrich Macao's existing cross-cultural atmosphere' (Forum Macao 2018c). ${ }^{4}$ However, the Lusofonia Festival has been taking place for more than twenty years, while the Culture Week, created in 2008, was a way to reinforce cultural exchange. Although these two events have different names, they replicate each other's agenda on different days of the same week.

Concerning this Cultural Week (Figure 14), the text notes that it reflects Macao's 'cultural umbilical cord' and that, throughout the past nine editions, Macao has been acclaimed as being a 'cultural exchange platform between China and Portuguese-speaking Countries', bringing together local artists and artists from those countries as well as other personalities in the cultural
3. The last governor of Macao, in the 1990s, was Vasco Rocha Vieira.

4. This official information about the Forum Macao contrasts, however, with the effective efficiency of this entity, the role and dynamics of which have been criticized by other unofficial sources. However, this article does not aim to investigate these aspects. 


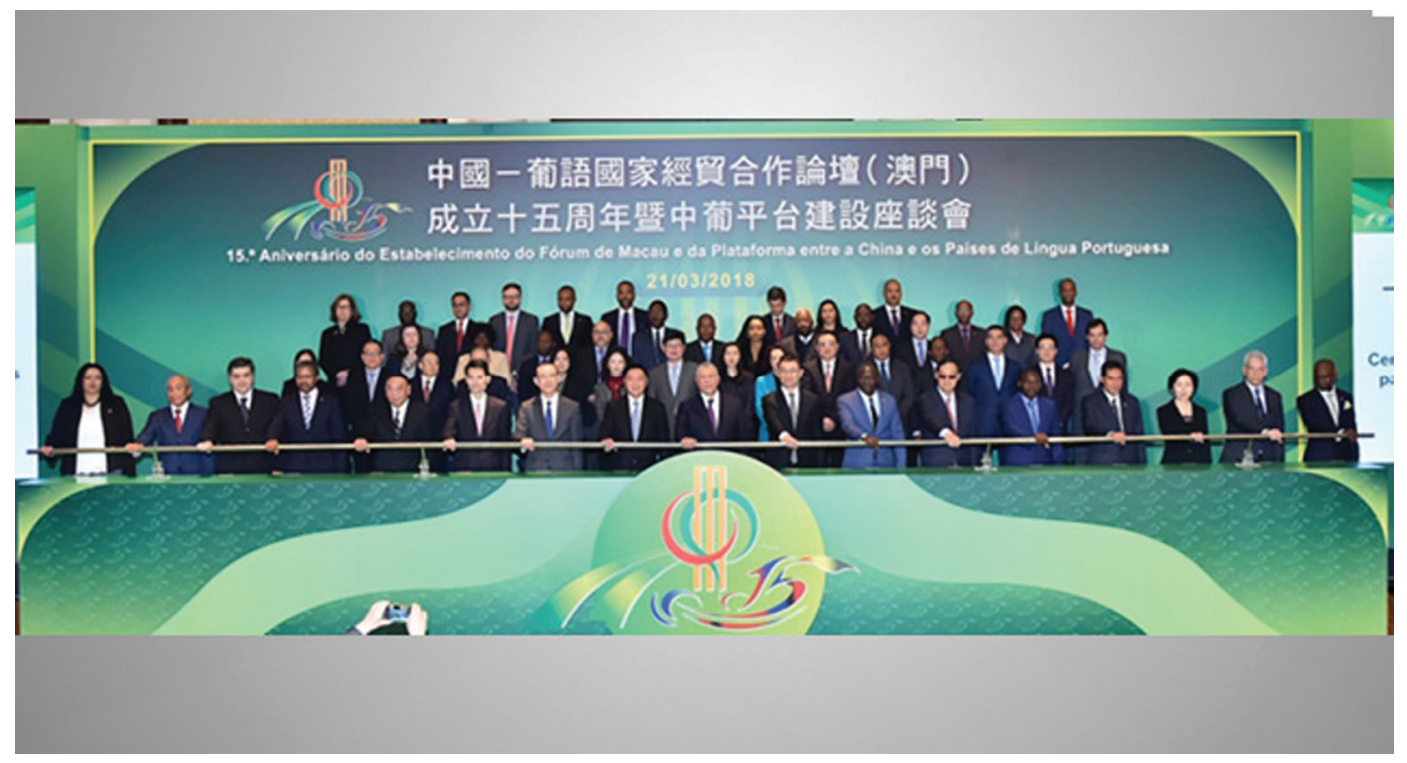

Figure 13: Seminar on the fifteenth anniversary of Forum Macao and the positioning of Macao as a platform between China and Portuguese-speaking countries (Forum Macao 2018a).

field. Some of those invited took part in shows, while others showcased their 'gastronomic skills or their talent in art or in crafts' (Forum Macao 2018c).

The gastronomical element deserves special attention since Macanese ethnicity and culture are also declared by claiming cultural items, such as Macanese cuisine as part of its heritage, considering that, since 2012, it has also been listed as UNESCO Intangible Cultural Heritage. The list includes chá gordo (literally 'fat tea') and other Macanese recipes that began being published from the late 1980s and early 1990s (Gaspar 2018).

Therefore, the claim for a Portuguese expression heritage developed in Macao, which is celebrated and widely publicized, strengthens the bonds between the MSAR, China and Portugal. On the other hand, China currently leverages these strategies so that, through Macao, it can move closer to Portuguese-speaking countries and Europe.

\section{CONCLUSION}

In the colonial context, Macao was seen and represented as a remote territory of which very little was known. However, while studying the representations of the territories under Portuguese colonial administration, it is clear that Macao enjoyed a privileged status in that setting, particularly in comparison with the depictions of African territories and Timor.

The so-called customs and practices of Macao were seen as both original and born of a meeting of several cultures. On the other hand, (gambling) addictions are mentioned, as well as the fact that the law is rather lenient. The fascination for Macao was often related to its alleged exoticism and to the fact that we can find elements that are identifiable with Portuguese culture in such a distant and different land.

There is a new generation of Macanese that identifies less with the Portuguese culture and that has begun to cultivate a new identity discourse. 

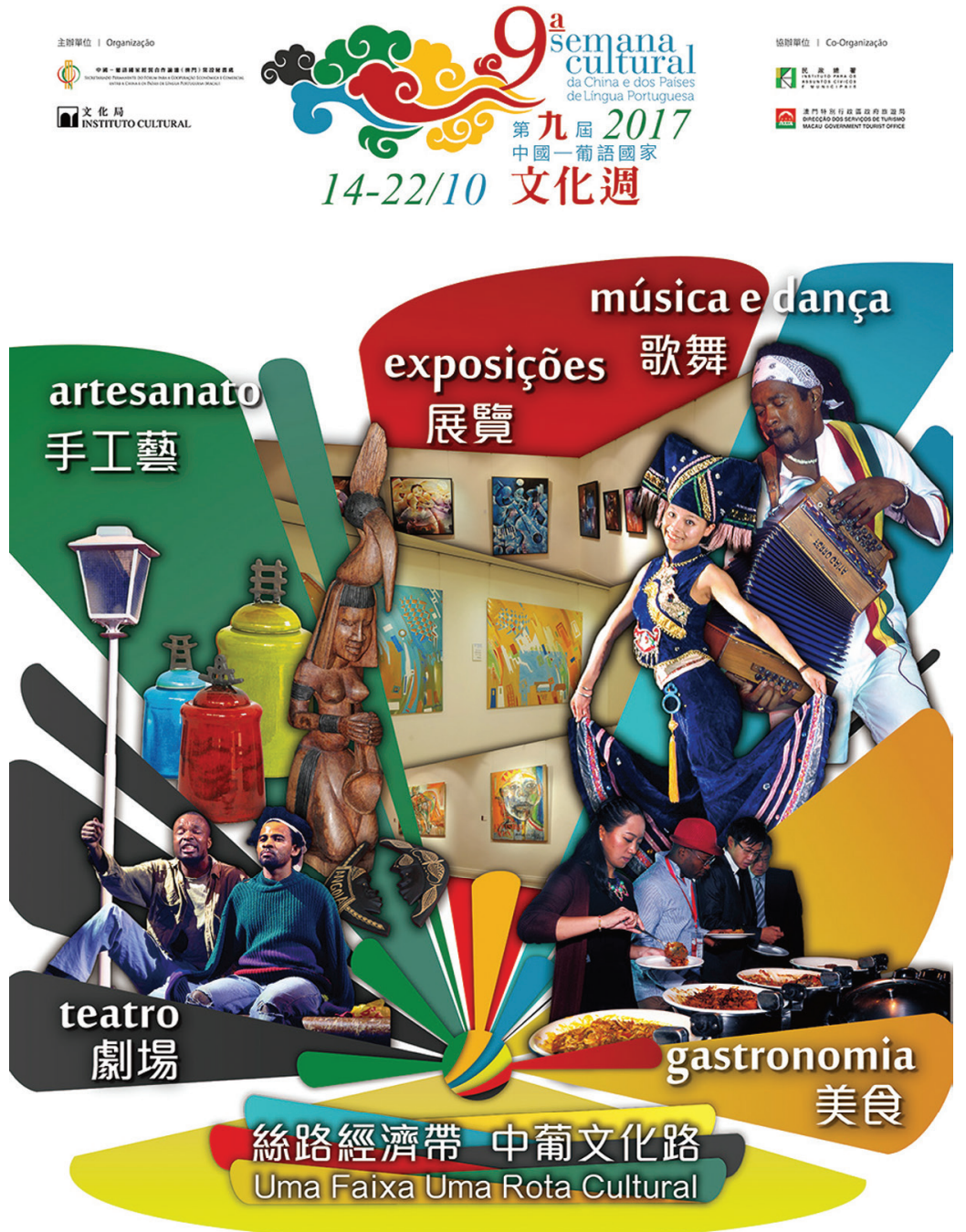

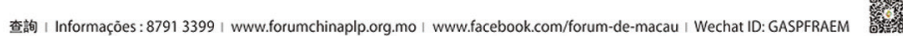

Figure 14: Portuguese-speaking countries and China Cultural Week poster, 2017.

During the transition period, both Portugal and China launched a campaign celebrating Macao's glorious past and re-creating this land as a unique space in China, as a product and a symbol of cooperation and cultural sharing between 'the East and the West'. This heritage was promoted in museums, folklore societies and other bodies that are developing an educational role in the process of building the MSAR nation (Gaspar 2014: 24). 
The Macanese community currently illustrates an agglutination process for the creation of an ethnic identity. It is a collectivity that defines itself by reference to a common origin, an imagined and continuously mutating entity, the continuity of which depends on agreements and negotiations between its members. These are connected by personal or family relationships and build their present based on heritages of the past (Gaspar 2014: 33).

It is also interesting to note the movement towards the internationalization of Macao and China. This movement sets course through Portugal, or the presence of the Portuguese community in Macao, which is often seen as being open to the world and with a remarkable ability to adapt to foreign territories. This fact is sometimes translated into the recruitment of Portuguese professionals in Macao - as they are considered highly qualified for establishing relationships with other Portuguese-speaking countries. As in the past, and despite all transformations, the harbour city of Macao is still an interesting place for reflecting on power and internationalization strategies, establishing relationships, the circulation of individuals and the formation of identities.

\section{ACKNOWLEDGEMENTS}

This work was financed by national funds through the FCT, I.P., under the Norma Transitória - DL57/2016/CP1441/CT0001. The translation of this text was financed by national funds through the FCT, I.P., within the Project UID/ SOC/50013/2019.

\section{REFERENCES}

Administrative Public Service Bureau of the Macau Special Administrative Region (2020), https://www.gov.mo. Accessed 26 June 2020.

Álbum-Catálogo Oficial (1934), O Império Português na Primeira Exposição Colonial Portuguesa realizada no Palácio de Cristal do Porto de Junho a Setembro do ano de 1934 ("The Portuguese empire at the first Portuguese colonial exhibition held at the Oporto Crystal Palace from June to September 1934'), Porto: Leitão.

Álbum Fotográfico (1934), Primeira Exposição Colonial Portuguesa: 101 clichés fotográficos de Alvão ('First Portuguese colonial exhibition: 101 Alvão photographic clichés'), Porto: Litografia Nacional.

Amaro, A. M. (1988), Filhos da Terra (Children of the Land), Macao: Instituto Cultural de Macau.

Anon. (1940), ‘Número Extraordinário Comemorativo do Duplo Centenário da Fundação e Restauração de Portugal' ('Extraordinary commemorative number of the double centenary of the foundation and restoration of Portugal'), O Século, June, n.pag.

Barreiros, L. D. (1940), Report on the Indigenous Representation of Macao, 11 August, process no. 4/64, subject 'Exhibition of the Portuguese World', Lisbon: Arquivo Histórico Ultramarino.

Boxer, C. (1963), Race Relations in the Portuguese Colonial Empire, 1415-1825, Oxford: Clarendon Press.

Boxer, C. (1969), The Portuguese Seaborne Empire, London: Hutchinson.

Brandtstädter, S. and Santos, G. D. (eds) (2009), Chinese Kinship: Contemporary Anthropological Perspectives, London: Routledge.

Cahen, M. and de Matos, P. F. (eds) (2018), Portuguese Studies Review, Special Issue: 'New Perspectives on Luso-Tropicalism', 26:1. 
Forum Macao (2018a), 'Seminar on the 15th anniversary of Forum Macao and the positioning of Macao as a platform between China and Portuguese-speaking countries', Macao, http://www.forumchinaplp.org. mo/seminar-on-the-15th-anniversary-of-forum-macao-and-the-establishment-of-the-platform-between-china-and-the-portuguese-speakingcountries/?lang=pt. Accessed 10 April 2018.

Forum Macao (2018b), 'Introduction', http://www.forumchinaplp.org.mo/ about-us/mission-and-objectives/?lang=pt. Accessed 10 April 2018. [no longer available].

Forum Macao (2018c), 'Cultural exchanges between China and Portuguesespeaking countries', http://www.forumchinaplp.org.mo/about-us/missionand-objectives/?lang=pt. Accessed 10 April 2018. [no longer available].

Galvão, H. (1940), Exposição do Mundo Português: Secção Colonial ('Exhibition of the Portuguese World: Colonial section'), Lisbon: Neogravura.

Gaspar, M. (2014), 'Macanese family genealogies: Memories and identities', Revista de Cultura, 46, pp. 20-36.

Gaspar, M. (2018), 'Património à mesa dos macaenses em Portugal' ('Heritage at the Macanese table in Portugal'), Trabalhos de Antropologia e Etnologia, 58, pp. 665-80.

Hall, S. (1997), 'The work of representation', in S. Hall (ed.), Representation: Cultural Representations and Signifying Practices, London: Sage, pp. 13-74.

de Matos, P. F. (2010), 'A História e os Mitos: Manifestações da ideologia colonial na construção do Portugal dos Pequenitos em Coimbra' ('History and myths: Manifestations of colonial ideology in the construction of Portugal dos Pequenitos in Coimbra'), $7^{\circ}$ Congresso Ibérico de Estudos Africanos 50 anos das independências africanas: desafios para a modernidade ('Seventh Congress of African Studies - 50 years of African independence: Challenges for modernity), Lisbon, 9-11 September, bit.ly/matos2010. Accessed 12 September 2020.

de Matos, P. F. (2013a), The Colours of the Empire: Racialized Representations during Portuguese Colonialism, Oxford and New York: Berghahn Books.

de Matos, P. F. (2013b), 'Entre el mito y la realidad: Desplazamientos de personas, propaganda de Estado y imaginación del Imperio Colonial Portugués' ('Between myth and reality: Displacement of people, state propaganda and the imagination of the Portuguese colonial empire'), Studia Africana, 24, pp. 11-28.

de Matos, P. F. (2014), 'Power and identity: The exhibition of human beings in the Portuguese great exhibitions', Identities: Global Studies in Culture and Power, 21:2, pp. 202-18.

Morais, I. (2018), 'Macau entre a "China Tropical" e a lusofonia a Oriente: Algumas achegas sobre os contextos colonial e pós-colonial' ('Macao between "tropical China" and Lusophony in the east: Some insights into the colonial and post-colonial contexts'), Portuguese Studies Review, Special Issue: 'New Perspectives on Luso-Tropicalism', 26:1, pp. 63-98.

O Cortejo Colonial no Porto (1934), exhibition guide, Porto, 30 September.

de Pina-Cabral, J. (2002), Between China and Europe: Person, Culture and Emotion in Macao, London: Continuum.

de Pina-Cabral, J. and Lourenço, N. (1993), Em Terra de Tufões: Dinâmicas da Etnicidade Macaense (In the Land of Typhoons: Macanese Ethnicity Dynamics), Macao: Instituto Cultural de Macau.

Restos de Colecção (2012), 'Exposição do Mundo Português em 1940' ('Exhibition of the Portuguese World in 1940'), bit.ly/3mewlCC. Accessed 10 April 2018. 
Ribeiro, A. L. (1947), O Cortejo Histórico de Lisboa, Portugal: Câmara Municipal de Lisboa, Arquivo Nacional das Imagens em Movimento and Cinemateca Portuguesa.

Said, E. (1978), Orientalism, New York: Pantheon.

Tavares, J. P. (1953), Livro de Leitura: Língua e História Pátria: Parte II (2. Ano) ('Reading book: Language and country history: Part II [2nd year]'), Lisbon: Livraria Sá da Costa.

Vieira, M. L. (1947), O Cortejo Histórico com a Representação de Todas as Colónias Portuguesas em Carros Alegóricos, Portugal: Arquivo Nacional das Imagens em Movimento.

\section{SUGGESTED CITATION}

de Matos, Patrícia Ferraz (2020), 'Colonial representations of Macao and the Macanese: Circulation, knowledge, identities and challenges for the future', Portuguese Journal of Social Science, 19:1, pp. 61-82, doi: https://doi. org/10.1386/pjss_00020_1

\section{CONTRIBUTOR DETAILS}

Patrícia Ferraz de Matos is an anthropologist and a research fellow at the University of Lisbon's Institute of Social Sciences (ICS). She has been a member of the teaching staff of the anthropology doctoral programme at ICS/ ISCSP-UL since 2013. She is convener of the EASA's Europeanist Network (2020-22), associate editor of Anthropological Journal of European Cultures (2020-22) and Portugal's corresponding member of the EASA's History of Anthropology Network (HOAN) since 2019. She is the author of As Côres do Império: Representações Raciais no Império Colonial Português (Imprensa de Ciências Sociais, 2012), which was published in English as The Colours of the Empire: Racialized Representations during Portuguese Colonialism (Berghahn Books, 2013). She obtained her doctorate in social and cultural anthropology in 2012 with a thesis about Mendes Correia and the Porto School of Anthropology. Prizes:Victor de Sá Prize in Contemporary History 2005; ERICS Prize (ICS/CGD) 2014; Scientific Prize - Honourable Mention (UL/CGD) 2019.

Contact: Instituto de Ciências Sociais, Universidade de Lisboa, Avenida Prof. Aníbal de Bettencourt, 9, 1600-189 Lisbon, Portugal.

E-mail: patricia_matos@ics.ul.pt

(1) https://orcid.org/0000-0001-7322-3756

Patrícia Ferraz de Matos has asserted their right under the Copyright, Designs and Patents Act, 1988, to be identified as the author of this work in the format that was submitted to Intellect Ltd. 